\title{
The Real Estate Market in the Aftermath of September 11
}

\author{
Jarl Kallberg, Crocker H. Liu, and Paolo Pasquariello ${ }^{1}$
}

June 1,2004

\footnotetext{
${ }^{1}$ Associate Professors of Finance, Department of Finance, Stern School of Business, and Assistant Professor of Finance, University of Michigan Business School. Please address comments to Paolo Pasquariello (corresponding author) at the Department of Finance, University of Michigan Business School, 701 Tappan Street, Suite D5210, Ann Arbor, MI 48109-1234 (Pasquariello), or via email: ppasquar@bus.umich.edu. Crocker Liu would like to thank the Salomon Center at the Stern School for financial support. We are grateful to Sreedhar Bharath and Ned Elton for helpful comments, and Jerry Crute for assistance with data gathering. All errors remain our own.
} 


\begin{abstract}
This study examines the reaction of the financial markets to the terrorist attack on the World Trade Center and how their behavior compared to the subsequent resolution in the corresponding real asset markets. This event provides an ideal setting to evaluate the accuracy of the market's reaction to external shocks since, unlike almost all studies of economic events, this tragedy was certainly unanticipated and thus absent from pre-existing market expectations, its overall impact was unclear, and the subsequent week of market closure gave market participants sufficient time to sort out the complex impact of the event on market prices. Our analysis of Real Estate Investment Trusts (REITs) with New York office exposure outside of the downtown area shows that, during the period of market closure and the first trading day, the equity market did not accurately anticipate how this event would impact office REITs. Specifically, we find that REITs with significant exposure to the New York market showed significant gains relative to REITs without New York exposure (an average difference of $4.057 \%$ of market value from the close on September 10 to the opening on September 17), and that this abnormal return disappeared only in November 2001. However, an examination of the underlying real asset market's performance over the first few months after September 11 shows that New York properties significantly under-performed similar office properties in the U.S. This evidence provides little support for the notion that financial markets can rapidly and correctly price significant shocks to the underlying economy.
\end{abstract}

JEL classification: G14; R33

Keywords: Abnormal Returns; Market Over-Reaction; Nonresidential Real Estate; REITs 


\section{Introduction}

A critical aspect of asset pricing is the degree to which current prices accurately reflect informed investors' expectations of future cash flows. This topic has been the subject of a voluminous and diverse literature. Cowles (1933) began this debate by raising the issue of how well market participants react to information, initiating the vast literature addressing market efficiency. ${ }^{1}$ Another important starting point in the analysis of stock market reactions to news is in the early behavioral economics research. An example is Kahneman and Tversky (1973), which suggested that individuals have a tendency to overweight recent news; see also Fama et al. (1969), Jegadeesh (1990), and Jegadeesh and Titman (1995). Numerous studies have documented market over-reaction. $^{2}$ Other studies find under-reaction. ${ }^{3}$ In addition, researchers have documented that markets appear to be "too volatile," in the sense that prices move much more than the levels justified by changes in "fundamentals." 4 Clearly the efficiency of the market's responses is still a contentious issue.

This study examines the equity market's reactions to one extremely dramatic event - the attack on the World Trade Center (WTC) on September 11, 2001- in order to evaluate the manner in which financial markets responded and how this response compares to the subsequent realized behavior of real asset markets. Besides the horrific loss of human life, the devastation was immense. As of December 21, 2001, it was estimated that 13.4 million square feet of office space was destroyed, 12.1 million was damaged and remained closed, and only 5.6 million was damaged but could be re-opened. ${ }^{5}$ To allow our empirical analysis to be focused and tractable, we study the market presumably most affected: The metropolitan New York office real estate market. From the perspective of mid-September 2001, the effect of this tragedy on the New York office market was not obvious. From the supply side, one could reasonably have assumed that the destruction of a vast amount of prime

\footnotetext{
${ }^{1}$ See Fama $(1991,1998)$ and Schwert (2003) for relatively recent surveys of market efficiency.

${ }^{2}$ DeBondt and Thaler $(1985,1987)$ address the link between mean reversion and investor over-reaction, showing that portfolios formed from poor performers had significantly higher abnormal returns than portfolios formed from good performers. The latter paper focuses on the controversial subject of time-varying risk premia. DeBondt and Thaler (1990) provides evidence of overreaction in analysts' forecasts. This paper builds on the earlier analysis of Elton et al. (1984), who show that analysts over (under) estimate the growth in earnings of firms they believe would be good (bad) performers.

${ }^{3}$ Cohen et al. (2002) is a recent example.

${ }^{4}$ See Shiller $(1981,1989)$ for an introduction to this topic.

${ }^{5}$ See Grubb and Ellis (2001).
} 
office space would drastically reduce supply and thus drive up the value of other New York office properties. ${ }^{6}$ Conversely, one could have presumed that the resulting shocks to an already teetering economy would have plunged the city of New York and the nation into a deep recession, negatively affecting the price of real estate (and other) assets. ${ }^{7}$

This event provides an ideal setting to evaluate the accuracy of the market's reaction to external shocks. Unlike almost all studies of important economic events, this tragedy was certainly unanticipated and thus could not have been built into pre-existing market expectations. The period of market closure that followed the attack (from Tuesday, September 11 to the following Monday, September 17) gave investors ample time to digest the relevant information and incorporate it into the prices that emerged when markets re-opened. ${ }^{8}$ Furthermore, our data set, by allowing us to compare the real and financial market performance of Real Estate Investment Trusts (REITs) with some New York exposure to those without, also enables us to separate the local effects from the shocks that affected the entire U.S. office real estate market. Finally, enough time has passed so that we can effectively evaluate the actual impact of the tragedy on the relevant markets.

Our research also complements existing work on stock market reactions to unanticipated events. Barrett et al. (1987) examine the stock market's reaction to airline crashes. Using event study methodology they find a significant negative reaction only on the event date. A number of studies have examined how bad news concerning a bank's clients can effect the price of bank stocks; see, for example, Smirlock and Kaufold (1987) or Sinkey and Carter (1999). There is also a substantial literature in the risk and insurance area dealing with the reactions of insurance company stocks to catastrophes; see, for example, Lamb (1995). An important difference between our study and this research is that, in our setting, the effect of the event of the relevant security prices was ambiguous rather than ex ante negative. For example, it was unclear whether or not the negative shock to the New York economy would outweigh the positive impact of a decrease in supply.

We study all public REITs that specialize in office properties. However, we exclude from our sample the two office REITs that owned properties in the downtown area. This exclusion allows us to assess the performance of the

\footnotetext{
${ }^{6}$ The New York office area is the largest office market in the U.S., representing approximately $9 \%$ of its total urban office space. At the time of the September 11 attack, the office vacancy rate in New York was only $3 \%$.

${ }^{7}$ We document these conflicting viewpoints in Section 4 by examining analysts' reports in the months following September 11.

${ }^{8}$ French and Roll (1986) provide an analysis of volatility during periods of market closure.
} 
underlying office properties by the end of the last quarter of 2001. As noted earlier, we examine performance in the real markets for the three months following the attack. This horizon is a balance between having enough time to assess the economic impact on the real markets, but short enough so that unrelated factors do not contaminate our performance measurements. The impact on properties in the damaged areas involved highly complex insurance claims that were far from being resolved in the first three months after $9 / 11$. The resulting sample of 27 office REITs allows us to study the market's expectations about the impact of September 11 on the remaining supply of New York office space, both in an absolute sense and in relation to other U.S. office properties. We estimate the actual and adjusted (relative to the Dow Jones 30 and to an index of REIT stocks) returns realized over the period of the market closure that followed this event to evaluate the "market's" estimate of the relative losses or gains that would accrue to those REITs. ${ }^{9}$ We then examine the realized performance in the real markets (i.e., the physical, rather than the securitized assets) over the first few months that followed September 11.

The main hypothesis tested is whether the equity market reacted accurately in the sense that its estimation of the future stock price performance of these equities was a reasonable expectation of the future performance. Specifically, we test whether these REITs' stock price changes immediately after the market closure between September 11 and September 16, 2001 are consistent with the subsequent real asset performance of the office REIT market. REITs provide an ideal structure for testing this hypothesis for a number of reasons: (i) because of the availability of data on REIT holdings we can accurately estimate each REIT's exposure to the metro New York market; (ii) detailed data on the performance of the underlying real asset markets are available; (iii) the performance of the REITs with New York exposure can be benchmarked against REITs without New York exposure to control for macro real estate market effects.

To briefly survey our results, we find evidence of a statistically and economically significant wedge between the financial and real market's assessment of the impact of the events of September 11 on New York REITs' valuations. More specifically, we show that the equity market anticipated that REITs with exposure to the New York market would achieve significant gains relative to their benchmark: REITs with significant exposure to the New York market in fact experienced an average excess return of $4.057 \%$

\footnotetext{
${ }^{9}$ We use the Dow Jones 30 in order to facilitate a comparison of individual REIT prices with individual industrial firm prices over this time period. From September 10 to the open and close on September 17, the S\&P500 lost somewhat less than the Dow Jones 30 $(-4.694 \%$ versus $-5.047 \%$, respectively).
} 
from the close on September 10 to the opening on September 17 relative to a broad REIT index. However, we then show that this reaction was inconsistent with what eventually occurred in the real asset markets: Indeed, New York properties significantly under-performed similar office properties in the U.S. over the first three months following the tragedy, according to several measures of real asset performance. Consistently, the initial euphoria of the equity market was short-lived: The cumulative abnormal returns on New York REITs drifted to zero by early November. Thus, this study finds little support for the notion that financial markets can rapidly and correctly price multifaceted and enormous shocks to the economy.

In the finance literature, to our knowledge, there are only three other papers that analyze September 11. Carter and Simkins (2002) document the differences in the price declines across the public airlines and link this distinction to anticipated variation in bankruptcy potential. Straetmans et al. (2003) use extreme value analysis to conclude that, after $9 / 11$, the expected frequency of "co-crashes" increased, but this change was statistically insignificant. The impact of September 11 on insurers is analyzed in Doherty et al. (2003). While their focus is on testing the validity of several theoretical insurance models, their empirical analysis of the major insurance and reinsurance companies affected by this event suggests that (page 198): "Despite the uncertainty, the post-market behavior was broadly predictable from existing economic models." Our work differs from these papers (and the previously cited research on market reactions to unanticipated events) most importantly because our focus is on a comparison of the financial markets' expectations versus the real markets' realizations.

The organization of the remainder of this paper is as follows. Section 2 describes the relevant REIT data set; a discussion of the key aspects of the institutional structure of these securitized assets is in the Appendix. Section 3 presents and analyzes our empirical results. Section 4 investigates the significance of several alternative explanations for the REITs' reaction to the events of September 11. Section 5 concludes.

\section{Data Description}

We assembled our REIT sample from the SNL REIT database. ${ }^{10}$ We use SNL's classification to obtain all REITs having an office property orientation (29 REITs), but exclude those with any exposure to downtown Manhattan (Brookfield Properties and TriZecHahn Corporation). We are then left with a

\footnotetext{
${ }^{10}$ SNL Financial is the premier financial information provider for in-depth coverage of the real estate sectors.
} 
sample of 27 REITs, which we use in the analysis that follows. Since SNL also reports the location and square feet ${ }^{11}$ of each property in a REIT's portfolio, we segment our sample of office REITs into those having a New York City or New York metropolitan area exposure and those that don't. We define the New York metropolitan area as New York City (excluding downtown Manhattan), the outer boroughs (Brooklyn, Queens, Staten Island, The Bronx), Long Island (including Nassau and Suffolk), Westchester (including Rockland County), Southern Connecticut (including Fairfield, Hartford, and New Haven counties), and Northern New Jersey (including the following counties: Bergen, Essex, Hudson, Morris, Passaic, Sussex, Union, and Warren). For each office REIT in our sample, we calculated the total square feet for its office properties in New York City, and also in the New York metropolitan area. We scaled these figures by dividing each by the total square feet of office space in the entire REIT portfolio. This yields the percentage of an office REIT's square footage that is in New York City (PctNYC) and the percentage of an office REIT's square footage that is in the New York metropolitan Area (PctNYMetro).

We obtained close-to-close daily REIT returns from CRSP, the threemonth Treasury Bill rate from the Federal Reserve, ${ }^{12}$ and the daily return on the Morgan Stanley REIT Index (MSREIT), a capitalization-weighted benchmark index of the most actively traded REITs, over the interval 01/02/199809/17/2001 from Bloomberg. Opening and closing daily prices for REITs as well as the Dow Jones Industrial Average and the S\&P500 from the close on Monday, September 10, 2001 to the open and close of Monday, September 17, 2001 are obtained from the website http://finance.yahoo.com.

Quarterly cap rates on real estate for New York and the nation, starting from the second quarter of 1994, are taken from three sources:

1. The American Council of Life Insurance (ACLI) publication Investment Bulletin: Mortgage Commitments on Multifamily and Nonresidential Properties reported by 20 life insurance companies;

2. The National Real Estate Index (NREI) Market Monitor;

3. Korpacz Real Estate Investor Survey published by Price Waterhouse Coopers $(\mathrm{PWC}) .^{13}$

\footnotetext{
${ }^{11}$ The square footage is reported for most properties except those that are raw land and those that are in the process of being developed (construction in progress).

${ }^{12} \mathrm{Http}: / /$ www.federalreserve.gov/releases/\#daily.

${ }^{13}$ The three sources of data differ. The Korpacz Real Estate Investor Survey consists of quarterly survey results from major institutional equity real estate market participants. Those surveyed provide their expectations for returns on investments in institutional-
} 
The cap rate is the ratio between the EBITDA and Firm Value on direct real estate investment. ${ }^{14}$ Its reciprocal, known as the EBITDA multiple, is a very familiar valuation metric in Finance. ${ }^{15}$ Thus, to value the property portfolio of a REIT, we employ the cap rate valuation model commonly used by real estate appraisers. A real estate appraiser first calculates the average cap rate for comparable properties. Next, he/she multiplies the reciprocal of the cap rate by the EBITDA of the appraised property (called the stabilized net operating income) to obtain an estimate of the property value. Finally, the mortgage amount is subtracted from the resulting value of the property to obtain the value of the equity.

We use the quarterly cap rates in conjunction with EBITDA for each REIT taken from the SNL REIT database to calculate the Net Asset Value (NAV) per share for each REIT. ${ }^{16}$ Each REIT's NAV is computed as the ratio between its trailing twelve-month EBITDA and its blended cap rate. Individual blend cap rates are weighted averages of either actual (from NREI and ACLI) or expectational (from PWC) cap rates for both New York and the U.S., with weights given by the REIT's exposure to the NY metropolitan area (again excluding downtown Manhattan). NAVs per share are computed to control for the possibility that the REITs added properties to their portfolios and financed the purchase with a secondary stock offering.

grade, real property. These expectations do not necessarily reflect the actual performance of such property. In contrast, NREI reports actual transactions of large income-producing properties and includes the transactions of REITs and real estate operating companies. The index attempts to keep quality constant by tracking only commercial real estate transactions that meet pre-specified property characteristics. The ACLI also reports actual transactions of institutional grade real property made by 20 life insurance companies. The ACLI data differs from that of NREI in that no attempt is made to keep the quality constant.

${ }^{14}$ Real estate practitioners define the cap rate as the ratio of "net stabilized" operating income (NOI) to the transaction price (or market value) of a property. "Net stabilized" means that the income figure used in the numerator of the ratio assumes that full lease up of the building has occurred such that the building's vacancy is equal to or less than the vacancy of the market. Operating income is the difference between total rental revenue from properties and the corresponding property operating costs. The SNL REIT database reports property income and expenses in addition to REIT (firm) income and expenses.

${ }^{15}$ For example, in valuing the equity of a given firm a financial analyst using a relative valuation methodology will compute the EBITDA multiple for a set of comparable firms. The average of these multiples will be multiplied by the EBITDA for the subject firm to estimate its enterprise value. Finally, the value of the firm's debt is subtracted from the estimated total firm value to impute the equity value.

${ }^{16}$ When these data were missing from the SNL REIT database, we obtained them from the REITs' 10Q forms. 


\section{Empirical Results}

\subsection{Results from the Financial Markets}

Table 1 presents the basic characteristics of the 27 REITs in our sample. Each is mainly involved in office properties, although three REITs with substantial holdings in the New York metropolitan area (Forest City Enterprises, Lexington, and Voronado) are more diversified. Our analysis will focus on the group of 12 that have significant exposure to New York office properties (except downtown Manhattan, by construction); we dub this group the New York REIT group. Of our New York REIT sample, three have over half of their total holdings in the New York area: SL Green (100\%), Reckson Associates (93\%) and Mack-Cali Realty (62\%). The remaining 15 have zero investment (as of September 2001) in the New York area. They represent a control sample in order to capture the more general effects of the event on the overall real estate market; we call this subset the national group.

Table 2 documents the stock market behavior of these REITs over the period from the close of the market on Monday September 10 to the open (column 2) and close (column 3) on Monday September 17, the first trading day after September 11. It is important to test the price behavior both at the opening, which incorporates the information over the period of the market closure, and, as a robustness check, at the close of the first trading day as well. The latter in fact captures the impact of any new information on the stock market's reaction to the crisis and is unaffected by distortions that can occur in opening prices. Panel A gives the unadjusted percentage change. The New York group gained an average of $1.998 \%$ to the open, but gave almost all of it back over the course of the trading day to close at a small average gain of $0.390 \%$. Conversely, the national group opened $2.075 \%$ lower and then lost a further $1.291 \%$ to close at a loss of $3.366 \%$. In both of these cases the New York average is significantly greater than the national average at the $5 \%$ level. This indicates that the market believed that the entire real estate sector would suffer because of the event, but that (presumably because of the reduced supply) New York office REITs would appreciate in value. Similarly, based on the standard deviation of returns, the dispersion of opinion was significantly higher (at least at the $10 \%$ level) for the New York group. The standard deviations at the open and close are in fact $5.683 \%$ and $3.493 \%$ for the New York group versus $1.676 \%$ and $2.344 \%$ for the national group. Panel B performs the same calculations with New York REIT returns relative to the Dow Jones 30 Index, which opened $6.798 \%$ lower than on September 10 and lost another $1.32 \%$ during the day. The New York group now shows a relative gain of $8.796 \%$ to the open and $8.509 \%$ to the close. 
Table 3 presents the cross-sectional correlations of the REIT groups. It shows that the correlation between the price change (close-to-open) and the percentage of property held in the New York area (excluding downtown Manhattan) is 0.781. The same correlation versus just New York City is 0.600. This suggests that the shock to supply is a strong factor in the market's revised value estimates. Figure 1 clarifies this correlation analysis. Figure 1a plots the percentage price change (close-to-open) versus the amount of square footage in the New York metropolitan area. The positive slope is obvious, as is the clustering of negative returns for REITs with zero New York exposure. Figure 1b, which plots the same price change versus a REIT's percentage exposure to the New York metropolitan area presents a similar picture. Again the slope is positive and REITs with zero New York exposure have negative returns. These results indicate that the market believed that the national real estate office sector would suffer because of the event, but that (presumably because of the reduced supply) New York office REITs would appreciate in value.

In Table 4 we estimate the (excess, if any) REIT market reaction to the events of September 11. We use the following return generating process to compute "normal" and "abnormal" returns: ${ }^{17}$

$$
r_{i t}^{C C}-r_{F t}=\alpha_{i}+\beta_{i}\left(r_{M t}-r_{F t}\right)+\varepsilon_{i t},
$$

where $r_{i t}^{C C}$ is the return on REIT $i$ from the close on day $t-1$ to the close on day $t, r_{F t}$ is the yield on the 90-day Treasury bill on day $t$, and $r_{M t}$ is the return on day $t$ on the Morgan Stanley REIT index. Eq. (1) is estimated over the interval January 2, 1998 - September 10, 2001 for each of the REITs in the sample. We then use those coefficients to compute normal close-toclose REIT returns $\widehat{r}_{i T^{*}}^{C C}$ on day $T^{*}=$ September 17,2001 , i.e., from the close on September 10 to the close on September 17. The resulting $R^{2}$ s are quite high for daily data, averaging about 21\%. The average estimates of $\alpha_{i}$ and $\beta_{i}$ in Eq. (1) are -0.0002 and 0.925 , respectively, indicating a satisfying performance of the benchmark. The national group showed no abnormal returns as well: Each of the estimated $\alpha_{i} \mathrm{~s}$ is in fact statistically insignificant.

According to Table 4, REITs with exposure to the New York metropolitan area out-performed the overall U.S. real estate market by a statistically significant $4.1 \%$ on average: $r_{i T^{*}}^{C C}-\widehat{r}_{i T^{*}}^{C C}=0.041$ in row NY of Table 4 . The out-performance of the New York REIT group was even more pronounced at the opening of trading. Normal close-to-close New York REIT returns $\widehat{r}_{i T^{*}}^{C C}$

\footnotetext{
${ }^{17}$ Kallberg et al. (2000) show that a one-factor return generating process with a REIT index as the factor performs as well as more complex models (e.g., using Fama-French and other factors).
} 
from Eq. (1) are estimated to be about 5.7\% lower than the corresponding return from the close on September 10 to the open on September 17, $r_{i t}^{C O}$. Furthermore, estimated abnormal returns are the greatest for REITs for which close-to-open returns $r_{i T^{*}}^{C O}$ are positive on September 17; 88\% of those REITs had office properties in New York.

\subsection{Results from the Real Markets}

The above evidence clearly indicates that the U.S. equity market expected that the impact of reductions in supply would outweigh the potential negative economic factors and thus moved the prices of REITs with New York exposure significantly higher than REITs without New York exposure. We now turn our attention to the actual performance of the underlying real assets over the three months that followed the event in order to gauge the accuracy of the market reaction. This interval was chosen in order to have enough time for the key uncertainty surrounding the crisis to be resolved, but short enough so that other exogenous factors do not begin to play an important role in real asset returns.

We use a variety of measures of real market performance based on expectational and realized data in order to present a robust analysis. We focus on different measures of quarterly internal rates of return (IRRs) for each of the REITs in the sample, irr $_{i \tau}$, and compare them to benchmark IRRs given by weighted averages of New York and national real rates of return. Specifically, we compute excess IRRs in three steps. First, we compute "normal" quarterly real rates of return for NY office REITs estimating the following regression over the time period 1994.Q2 to 2001.Q2 (29 observations):

$$
i r r_{\tau}^{N Y}-r_{F \tau}=\alpha+\beta\left(r_{U S \tau}-r_{F \tau}\right)+\eta_{\tau},
$$

which mimics Eq. (1) using rates of return from real rather than financial markets. Here $i r \tau_{\tau}^{N Y}$ is the estimated rate of return on our New York sample, $r_{F \tau}$ is the yield on the 90-day Treasury bill over quarter $\tau$, and $r_{U S \tau}$ is the nation-wide real estate IRR in quarter $\tau$ from the Korpacz Data Index, which is constructed with a variety of measures of real market performance (see Section 2). Second, the resulting estimated coefficients $\widehat{\alpha}=0.003$ and $\widehat{\beta}=$ 0.831 , are used to compute "normal" NY REIT returns, $\widehat{i r r}_{\tau^{*}}^{N Y}=i r r_{\tau^{*}}^{N Y}-\widehat{\eta}_{\tau^{*}}$ for $\tau^{*}=2001$.Q4, to control for the impact of the idiosyncratic events of September 11 on the NY office business. The $R^{2}$ of $83 \%$ indicates that Eq. (2) does an excellent job of describing NY REITs' real returns. Finally, excess IRR for each REIT in quarter $\tau^{*}=2001$.Q4 is computed as the difference between its quarterly IRR, $i r r_{i \tau^{*}}$, and the corresponding benchmark $i r r_{i \tau^{*}}^{B}=$ 
$\omega_{i} \widehat{\hat{r r r}}_{\tau^{*}}^{N Y}+\left(1-\omega_{1}\right) r_{U S \tau^{*}}$, where $\omega_{i}$ is the percentage of the REIT $i$ 's office space in the NY metro area reported in Table 1.

Table 5a reports estimated excess IRRs measured using the percentage quarterly change in Net Asset Value (NAV) for each REIT in the sample computed using three different blend (i.e., weighted) cap rates: The NREI data in columns 3 and 4, the ACLI data in columns 5 and 6, and the expectational data from PWC in columns 7 and 8 (see Section 2). The most striking result is the difference between the ensuing average abnormal real returns and the estimated excess REIT returns in Table 4. Table 5a shows in fact that the real abnormal returns to the New York REITs over the quarter immediately following $9 / 11$ were either statistically significantly negative or zero, in contrast to their positive relative performance in the financial markets over the period of market closure (4.1\% in Table 4). More specifically, the sample average abnormal real returns for NY REITs, $i r r_{i \tau^{*}}-i r r_{i \tau^{*}}^{B}$, based on each of the three measures above, were $-3.3 \%, 0.4 \%$, and $-3.0 \%$, respectively. In addition, although the real market performance of the national group was somewhat lower, according to each of our three metrics, the differences between the two groups were never statistically significant. Similarly, REITs that increased in price from close-to-close out-performed those that lost by $3.3 \%, 3.6 \%$, and $1.1 \%$, respectively, while REITs that had positive returns at the open on September 17, $2001\left(r_{i T^{*}}^{C O} \geq 0\right)$ out-performed those REITs with negative returns at the open $\left(r_{i T^{*}}^{C O}<0\right)$ in two of the three cases (using NREI and ACLI measures). Yet again none of these differences was statistically significant.

Table 5b reports the same analysis when NAVs are calculated with only U.S. cap rates, to ensure that our results are not driven by the procedure used to compute blend cap rates. The results parallel those obtained in Table 5a. The under-performance of the New York group is now more pronounced, and significantly negative, for each of the three measures. The New York group again out-performed the national group, although now the differences are much smaller: about 1.0\% using either NREI, ACLI, or PWC data. However, REITs that gained or lost during the first trading day had virtually identical performance. Moreover, none of these differences is statistically significant, as in Table 5a. We obtained similar results (not reported here) by computing REIT IRRs from changes in their Net Equity Values (NEV), equal to their NAVs minus Debt. Overall, this evidence offers little support for the notion that the U.S. equity market correctly interpreted the available information when formulating its expectations of relative REIT performance. 


\section{Explaining Financial and Real Results}

Our analysis suggests that the prices of REITs with New York exposure did not reasonably anticipate the subsequent resolution of uncertainty in the real asset markets. To help interpret our results, we need to verify that the movement in the real markets was an accurate reflection of the "true" price reaction. We address this issue in two ways. First, we examine the trading behavior of insiders in the weeks following September 11. If insiders believed that the prices of REITs with New York exposure would decline relative to their peers, then we should see a relatively higher amount of selling by the insiders of New York REITs. Second, we examine the abnormal returns on New York REITs in the weeks following the event. If the relative value of New York REITs were actually declining we would expect to see the abnormal returns drift towards zero as markets rationally correct their initial misperceptions.

Figure 2 performs the first of these tests. It shows the cumulative sums of scaled differences between total insider purchases and sales in REITs with (solid line) or without (dashed line) exposure to the New York metropolitan area (excluding downtown Manhattan) that are sales. The data are obtained from WRDS (Wharton Research Data Services) TFN Insider Filing Data Files. ${ }^{18}$ Figure 2 shows that, for the first seven months of 2001, the two cumulative ratios were almost identical for REITs with and without New York exposure. Indeed, the average percentage of sales was approximately $46 \%$ of all trades for both groups. However, in the first three months after September 11, insider sales exceeded insider purchases for REITs with New York exposure, hence the corresponding ratio trended downward and turns negative, while the ratio for the national group continued to trend upward. This divergence in selling and buying patterns suggests that insiders of the New York group used their information to increase the frequency of their selling activity. This is consistent with the notion that the markets had temporarily over-valued New York REITs relative to other office REITs.

The second test is depicted in Figure 3, which plots cumulative abnormal returns (CARs, solid line) for the REITs with NY exposure listed in Table 1 over the nine-month sample period from September 17, 2001 to June 17, 2002. We also plot a 95\% confidence interval (dashed lines) under the null

\footnotetext{
${ }^{18}$ This database, available at http://wrds.wharton.upenn.edu, contains all insider activity as reported on SEC forms 3, 4, 5, and 144. According to the WRDS documentation, "Corporate insiders are defined broadly to include those that have 'access to non-public, material, insider information' and these insiders are required to file SEC form 3, 4, and 5 when they trade in their companies stock." We were unable to compute dollar amounts for these trades because, in many cases, the actual transaction prices were not reported.
} 
hypothesis of no cumulative excess returns. CARs are generated by first computing close-to-close abnormal returns (ARs) estimated using the market model of Eq. (1) over the interval January 2, 1998 - September 10, 2001 (in Table 4) and then aggregating them over time and across REITs. CARs are initially highly positive and significant, as a result of the relatively superior performance of this group immediately after September 11. However, the solid line drifts quickly downward, crossing the upper bound of the confidence interval in early November before reaching zero immediately afterwards. In the following seven months, the CARs remain relatively small and almost always statistically indistinguishable from zero. Hence, Figure 3 shows that while the markets had initially misread the effect of September 11 on New York REITs, prices relatively quickly recovered.

While it is impossible to rigorously evaluate the possible reasons for our observed discrepancy between the reactions of real and financial markets to that event, one issue is clear. Financial markets anticipated that, in the New York metro area, the reduction in supply would be sufficient to generate above normal returns for office REITs with significant New York exposure. This assumption, as we have documented, turned out to be incorrect. Real estate practitioners cite two reasons for what went wrong with the financial market forecasts. In essence, these arguments involve the fact that employers laid off workers faster than they could layoff space. This factor, coupled with excess space known as "shadow" 19 space by New York metro area employers, resulted in a sufficient supply of space for displaced tenants. According to Grubb \& Ellis (2001), by December 2001, permanently displaced tenants contracted to take only $48 \%$ as much space as they had formerly occupied. In addition, since September 11, New York companies that were not directly effected re-evaluated their space needs and offered an additional 10.1 million square feet of space available for sublet. Much of this additional sublet space

\footnotetext{
${ }^{19}$ The National Association of Realtors (NAR) defines shadow space as space that isn't being occupied by the tenant but isn't being actively marketed either. Shadow space is a difficult number to obtain. In an RCA (Realtors Commercial Alliance) Report dated Fall 2003, Torto Wheaton research estimated that nationwide, shadow space represents an additional $3 \%$ of unoccupied space that is not reflected in vacancy numbers. Mitchell Stein, CEO of Julien J. Studley Inc., a commercial leasing agent, stated in the same report that shadow space for Manhattan accounts for between 2.5\% to 3.5\% (10 to 14 million square feet) of unoccupied space. Shadow space exists not only because firms can lay off workers faster than they can lay off space but also because companies worry they won't be able to find space in the future and thus take more than they presently require. There are other reasons why space remains in the shadows. These reasons include the fact that very small amounts of space are difficult to lease as well as space with only one to two years remaining on a lease is unmarketable except to very flexible tenants. Also the cost to reconfigure the space to make it subleasable might not be justified.
} 
came from Wall Street firms. Consequently, the amount of displaced tenants that were expected to lease new space somewhere in Manhattan was not as large as anticipated.

In addition to a reduction in the demand for space, corporations also downsized their workforce in the post 9-11 period. In New York City, the securities industry alone lost 9, 800 jobs; a total of 31,100 private sector jobs were lost in 2002, as the unemployment rate rose to $8.4 \%$. Besides an increase in vacancy, the anticipated increase in rents did not materialize in part due to the Real Estate Board of New York's (REBNY) written memo to its members that "Any member owner, firm, or broker found to be taking advantage of this terrible tragedy will be expelled from the Real Estate Board." 20 While some critics might argue that expectations might not have been realized because tenants moved out of the New York metro area, Table 6 shows that only a small portion (5.4\%) of tenants relocated outside of the metro area. The overwhelming majority of displaced tenants $(84.9 \%)$ chose to remain in New York City.

Finally, we consider the possibility that the discrepancy between the relative performance of financial and real markets for the NY REITs in our sample following September 11 may be due, at least in part, to the arrival of idiosyncratic news affecting those REITs between September 10 and September 17,2001 . We check for this argument by examining all relevant information events taking place for each of the 27 REITs in our sample over that interval of time. The ensuing sequence of these events (from Lexis-Nexus), reported in Table 7, suggests that none of the REITs under examination experienced information shocks significant enough to bias our statistical analysis, i.e., to contribute to the abnormal returns estimated in Table 4.

\subsection{REIT Analysts' Reports}

To further investigate the process of resolution of the uncertainty surrounding the behavior of the real markets following the events of September 11, we searched Investext for analyst reports regarding the impact of the World Trade Center attacks on REITs issued around the time of the attack. ${ }^{21}$ As

\footnotetext{
${ }^{20}$ According to the information reported on the website http://www.propertymag.com/property/Winter02/coverstory_print.html, REBNY urged its members not to take advantage of displaced tenants when negotiating lease rates and suggested using rental rates in place prior to September 11. REBNY also asked brokers to waive their usual commissions and fees in assisting displaced tenants who required short-term (less than 12 months) leases.

${ }^{21}$ Investext is currently the world's largest online database of company and industry investment research reports. These reports are not generally available through public channels.
} 
a specific illustration, we focus on analysts' reports for Mack-Cali (CLI). ${ }^{22}$ On August 16th, 2001 Morgan Stanley issued a note maintaining its position that Mack Cali was expected to "under perform" (even though they beat analyst estimates) based on erosion in market fundamentals and on the expected acceleration of their disposition program, which was expected to dilute earnings. ${ }^{23}$ This negative opinion was partly based on management lowering expected 2001 earnings to reflect potential occupancy erosion in their portfolio, the sustainability of rental rates, and the timing of the company's ongoing capital recycling program. Prior to $9 / 11$, REIT analysts from other investment banks held a similar opinion about the New York market and Mack-Cali in particular as Table 9 shows.

All of the reports that we found issued in the ten days following 9/11 indicated that REIT analysts expected New York area REITs to benefit from the anticipated scramble for space in both Midtown and in NJ, CT, Long Island, and Westchester based on an expected tightening of office market space in the short run. For example, from Axelrod (2001), "The taking out of 25 million square feet of Manhattan office space has dramatically tightened the entire NYC metro office market which stood at 7.5\% vacancy (direct and sublease, Manhattan only) at the end of Q201. However, for the rest of the national office markets, a recession is a decided negative." Given this anticipated reduction in supply, analysts raised their target price for REITs having a New York presence. From Raiman et al. (2001), “... in response to shrinkage of office supply in Manhattan - and its positive implication on the tri-state market, we are raising our target price to $\$ 34-35$ on Mack-Cali Realty given its office concentration in the Tri-State area."

However, analysts just one quarter later emphasized the fact that the anticipated occupancy pressure was not offset with increased Manhattan demand. As noted in Litt (2001), "The vast amount of 'phantom vacancy' that appeared in Manhattan following the attack will likely limit some of the upside we expected in Mack-Cali's 2002 occupancy as many displaced tenants have found space in Manhattan." Taylor (2001) agreed, stating, “... the WTC impact was short lived ... tenants in midtown New York have been rethinking their space needs and giving up space. This has relaxed the tightness in the NYC market that had driven demand to Harborside (in Jersey City). Like most investors and analysts, we thought there'd be a benefit from the loss of space in Manhattan. We thought it would be short term, but not this short." As Table 9 shows, Morgan-Stanley, Deutsche Bank, and CSFB

\footnotetext{
${ }^{22}$ Mack-Cali is an office REIT with a sizeable presence in the New York area (62\% of its office properties, based on square feet, according to Table 1).

${ }^{23}$ This report, Whyte (2001), was the last analyst report issued on Mack-Cali prior to the attack on the World Trade Center.
} 
all initially raised their recommendations and forward-looking EPS for the year ahead immediately after $9 / 11$, but then lowered them over the following few months.

\section{Conclusions}

The ability of financial markets to process available information quickly and accurately is the cornerstone of modern theories of market efficiency. This study examined the precision of the market's reaction to one very dramatic event, the terrorist attacks on September 11, 2001, and how this reaction compared to the subsequent behavior of the real asset markets. To that end, we chose to analyze the dynamics of returns of Real Estate Investment Trusts (REITs) exposed to the New York metropolitan area, with the exclusion of downtown Manhattan. Those attacks in fact inflicted significant damage to, and more generally shrank the available supply of New York office space. Moreover, information asymmetry surrounding their assets with respect to the average investor is generally lower than for the typical equity, since REITs' holdings are public knowledge.

We found economically and statistically significant evidence of a dichotomy between financial and real markets' assessment of the impact of the events of September 11 on New York REITs' valuations. Indeed, returns on New York office REITs from the close on September 10 to the open are September 17 and returns in the underlying real markets over the following quarter moved in opposite directions. In particular, New York REITs showed a significantly positive abnormal return of $4.1 \%$, while the corresponding real markets over the last quarter of 2001 showed significantly negative abnormal returns for 5 of our 6 measures of real performance. Hence, this evidence is inconsistent with the notion that financial markets are good predictors of future real shocks, unlike Doherty et al. (2003).

Finally, when attempting to interpret our evidence, we found that three plausible explanations for this discrepancy did not in fact play an important role in its occurrence. Firstly, we found that insiders of the New York REITs used their private information to increase the frequency of their selling activity, suggesting that they perceived markets had over-valued those REITs relative to their peers. Secondly, we showed that the abnormal New York office REIT performance was relatively short-lived, and that a correction of REIT valuations occurred in less than two months after September 11. Lastly, we could not identify any significant idiosyncratic information shock taking place during the ensuing, three-day long market shut-down for any of the REITs in our sample. Nonetheless, the weaker-than-expected real 
performance of NY REITs appears to be related to the ability of many downtown firms to reduce space requirements, after the forced relocation, and to lower-than-expected actual vacancy rates.

\section{Appendix: Institutional Features of REITs}

Congress created REITs in 1960 to provide individual investors a vehicle for owning income-producing real estate through pooling arrangements. The early REIT issues were viewed as passive diversification plays for individual investors but, as the market developed, they became alternatives to direct real estate investment for institutional investors.

It is important to our study to realize that the REIT structure make the analysis of their dynamics less difficult than for the typical equity. As detailed below, there are severe restrictions on dividend payout, which means that a REIT manager has much less discretionary cash flow than the manager of a normal corporation. In addition, the law restricts the types of activities in which a REIT can engage, thus limiting the manager's opportunities to fund negative NPV projects or projects that have significant private benefits. Finally, because the holdings of a REIT, mostly physical properties, are public knowledge, the informational asymmetry with respect to the average investor is also reduced. This is important when considering the implications of the WTC attacks on REIT's valuation.

A REIT is not taxed at the firm level if it satisfies the provisions outlined below. These regulations are designed to ensure that REITs, which hold a portfolio of properties and/or mortgages for the long term, will be passive investment vehicles similar in concept to open-ended mutual funds.

1. At least $95 \%$ of net annual taxable income is distributed to sharehold$\mathrm{ers}^{24}$

2. At least $75 \%$ of annual gross income comes from rents, mortgage interest, gains from selling real estate, and dividends from investing in other REITs;

3. At least $75 \%$ of all assets consists of real estate, mortgages on real estate, shares of other REITs, cash, or government securities;

4. At least $95 \%$ of the REIT's gross income comes from items qualifying under the $75 \%$ income test, dividends and interest income, and gains from the sale of stock and other securities;

\footnotetext{
${ }^{24}$ Recent regulatory changes (effective in the beginning of 2001) have changed this to $90 \%$ of taxable income.
} 
5. At least 100 shareholders must exist with no more than 50 percent of the shares held by five or fewer shareholders;

6. It must elect to be treated as a REIT;

7. Real property must not be held primarily for sale in the ordinary course of business (gains from the sale of property held for less than four years must comprise less than $30 \%$ of gross income);

8. Trustees, directors or employees of a REIT are restricted from actively managing or operating REIT property, although they are permitted to make property decisions if such decisions relate to the business of the REIT itself.

The REIT market has undergone numerous structural changes since its inception in 1960. REITs formed during the 1960s and 1970s were mostly engaged in higher-risk development and construction loans, and were illpositioned to withstand the real estate crash of the mid 1970s. REITs created in the 1980s were basically passive, diversified holdings of real estate. Most were finite-horizon REITs, which limited their growth potential. This market structure changed dramatically in the 1990s. The new REITs featured active management, low leverage, infinite lives and substantial insider holdings (often more than a third of the outstanding shares). These changes led to greater institutional ownership, as documented in Ling and Ryngaert (1997). For the pre-1990 REITs, institutional shareholders usually held less than $10 \%$ of the outstanding shares one quarter after the IPO. The corresponding figure for the post-1990 REITs is $42 \%$.

\section{References}

[1] Axelrod, S. (2001). Morning Meeting Note. Lehman Brothers, September 21, 2001.

[2] Barrett, W., A. Heuson, R. Kolb, G. Schropp (1987). The Adjustment of Stock Prices to Completely Unanticipated Events. The Financial Review, 22, pp. 345-354.

[3] Carter, D., B. Simkins (2002). Do Markets React Rationally? The Effect of the September 11th Tragedy on Airline Stock Returns. Working paper, Oklahoma State University. 
[4] Cohen, R., P. Gompers, T. Vuolteenaho (2002). Who Underreacts to Cash-Flow News? Evidence from Trading Between Individuals and Institutions. Journal of Financial Economics, 66, pp. 409-462.

[5] Cowles, A. (1933). Can Stock Market Forecasters Forecast? Econometrica, 1, pp. 309-324.

[6] Daniel, K., D. Hirschleifer, A. Subrahmanyam (1998). Investor Psychology and Security Market Under- and Over-Reactions. Journal of Finance, 53, pp. 1839-1885.

[7] DeBondt, W., R. Thaler (1985). Does the Stock Market Overreact? Journal of Finance, 40, pp. 793-805.

[8] DeBondt, W., R. Thaler (1987). Further Evidence on Investor Overreaction and Stock Market Seasonality. Journal of Finance, 42, pp. 557-581.

[9] DeBondt, W., R. Thaler (1990). Do Security Analysts Overreact? American Economic Review, 80, pp. 52-57.

[10] Doherty, N., J. Lamm-Tennant, L. Starks (2003). Insuring September 11th: Market Recovery and Transparency. The Journal of Risk and Uncertainty, 26, pp. 179-199.

[11] Elton, E., M. Gruber, M. Gultekin (1984). Professional Expectations: Accuracy and Diagnosis of Errors. Journal of Financial and Quantitative Analysis, 19, pp. 351-363.

[12] Fama, E. (1991). Efficient Markets II. Journal of Finance, 46, pp. 15751617.

[13] Fama, E. (1998). Market Efficiency, Long Term Returns and Behavioral Finance. Journal of Financial Economics, 49, pp. 283-306.

[14] Fama, E., L. Fisher, M. Jensen, R. Roll (1969). The Adjustment of Stock Prices to New Information. International Economic Review, 10, pp. 1-21.

[15] French, K., R. Roll (1986). Stock Return Variances: The Arrival of Information and the Reaction of Traders. Journal of Financial Economics, 17 , pp. 5-26.

[16] Grubb and Ellis Research, 2001. NYC's Office Market - A Post 9-11 Update. December. 
[17] Jegadeesh, N. (1990). Evidence of Predictable Behavior of Security Prices. Journal of Finance, 45, pp. 881-898.

[18] Jegadeesh, N., S. Titman (1995). Overreaction, Delayed Reaction, and Contrarian Profits. Review of Financial Studies, 8, pp. 973-993.

[19] Kahneman, D., A. Tversky (1973). On the Psychology of Prediction. Psychological Review, 80, pp. 237-251.

[20] Kallberg, J., C. Liu, C. Trzcinka (2000). The Value Added from Investment Managers: An Examination of Funds of REITs. Journal of Financial and Quantitative Analysis, 35, pp. 387-408.

[21] Lamb, R. (1995). An Exposure-Based Analysis of Property-Liability Insurer Stock Values around Hurricane Andrew. The Journal of Risk and Insurance, 62, pp. 111-123.

[22] Ling, C., M. Ryngaert (1997). Valuation Uncertainty, Institutional Involvement, and the under-pricing of IPOs: The Case of REITs. Journal of Financial Economics, 43, pp. 433 - 456.

[23] Litt, J. (2001). Mack-Cali (CLI): Occupancy Pressure Not Offset with Increased Manhattan Demand. Salomon Smith Barney, November 8, 2001.

[24] National Association of Realtors, RCA (Realtors Commercial Alliance) Report, Volume 4, Issue 4, Fall 2003, p. 4.

[25] Raiman, L., Dembski, M., Habermann, J., Schwalbe, J. (2001). Morning Meeting Note. Credit Suisse First Boston, September 17, 2001.

[26] Schwert, G. W. (2003). Anomalies and Stock Market Efficiency. Handbook of the Economics of Finance, Volume 1B, G. Constantinides, M. Harris and R. Stulz editors, Elsevier Press, Amsterdam.

[27] Shiller, R. (1981). Do Stock Prices Move Too Much to Be Justified by Subsequent Changes in Dividends? American Economic Review, 75, pp. 421-436.

[28] Shiller, R.(1989). Market Volatility, MIT Press, Cambridge MA.

[29] Sinkey, J., D. Carter (1999). The Reaction of Bank Stock Prices to News of Derivatives Losses by Corporate Clients. Journal of Banking and Finance, 21, pp. 1725-1743. 
[30] Smirlock, M., H. Kaufold (1987). Bank Foreign Lending, Mandatory Disclosure Rules and the Reaction of Bank Stock Prices to the Mexican Debt Crisis. Journal of Business, 60, pp. 347-364.

[31] Straetmans, S., W. Verschoor, C. Wolff (2003). Extreme U.S. Stock Market Fluctuations in the Wake of 9/11. Working Paper, Maastricht University.

[32] Taylor, L., Goebel, T. (2001). CLI: WTC Impact Is Short-Lived. Deutsche Banc Alex. Brown Inc., November 9, 2001.

[33] Whyte, G. (2001). Mack-Cali Realty: CLI; 2001 Guided Lower Despite 2Q01 Beat. Morgan Stanley, August 16, 2001. 


\section{Table 1. Sample REITs}

This table provides basic information for each of the 27 REITs included in our sample. The column labeled NY indicates the percentage of office space (in square feet) in the NY metro area in the portfolio of the corresponding REIT. The NY metro area includes New York City (but not downtown Manhattan), the outer boroughs (Brooklyn, Queens, Staten Island, The Bronx), Long Island (including Nassau and Suffolk), Westchester (including Rockland County), Southern CT (including Fairfield, Hartford, and New Haven counties), and Northern NJ (including the following counties: Bergen, Essex, Hudson, Morris, Passaic, Sussex, Union, and Warren).

\begin{tabular}{lcccc}
\hline \hline \multicolumn{1}{c}{ REIT name } & Ticker & Property focus & Region & NY \\
\hline Alexandria Real Estate Equities & ARE & Office & WE & $0.00 \%$ \\
AmeriVest Properties & AMV & Office & SW & $0.00 \%$ \\
Arden Realty & ARI & Office & WE & $0.00 \%$ \\
Bedford Property Investors & BED & Office & WE & $0.00 \%$ \\
Boston Properties & BXP & Office & NE & $18.37 \%$ \\
Brandywine Realty & BDN & Office & MA & $1.75 \%$ \\
CarrAmerica Realty & CRE & Office & MA & $0.00 \%$ \\
Corporate Office Properties & OFC & Office & MA & $3.19 \%$ \\
Crescent Real Estate Equities & CEI & Office & SW & $0.00 \%$ \\
Duke Realty & DRE & Office & MW & $0.00 \%$ \\
Equity Office Properties & EOP & Office & MW & $5.18 \%$ \\
Forest City Enterprises & FCEA & Diversified / Other & MW & $38.53 \%$ \\
Glenborough Realty & GLB & Office & WE & $4.58 \%$ \\
Great lakes REIT & GL & Office & MW & $0.00 \%$ \\
Highwood Properties & HIW & Office & SE & $0.00 \%$ \\
HRPT Properties & HRP & Office & NE & $32.29 \%$ \\
Kilroy Realty & KRC & Office & WE & $0.00 \%$ \\
Koger Equity & KE & Office & SE & $0.00 \%$ \\
Lexington Properties & LXP & Diversified / Other & MA & $8.55 \%$ \\
Mack-Cali Realty & CLI & Office & MA & $61.71 \%$ \\
Mission West Properties & MSW & Office & WE & $0.00 \%$ \\
Parkway Properties & PKY & Office & SE & $0.00 \%$ \\
Prentiss Properties & PP & Office & SW & $0.00 \%$ \\
Prime Group Realty & PGE & Office & MW & $0.00 \%$ \\
Reckson Associates Realty & RA & Office & MA & $93.48 \%$ \\
SL Green Realty & VNO & Office & DA & $100.00 \%$ \\
Vornado Realty & & MA & $43.26 \%$ \\
\hline \hline
\end{tabular}




\section{Table 2. Market reaction}

This table analyzes relative price changes of the REITs in our sample from the close on 09/10/2001 to the open and close of 09/17/2001. REITs with some NY metro exposure (see Table 1) are compared to those with none (Panel A) or to the Dow Jones Industrial Average (DJIA, Panel B), using one and two-tailed $t$-tests for average price changes and one-tailed $F$-tests for their variances. A "* " indicates significance of the $t$-statistic at the $5 \%$ level. $\mathrm{P}(\mathrm{F} \leq \mathrm{f})$ is the probability that two variances are not significantly different.

\begin{tabular}{|c|c|c|}
\hline \multicolumn{3}{|c|}{ Panel A: REIT comparison } \\
\hline & close-to-open & close-to-close \\
\hline \multicolumn{3}{|c|}{ Average price change } \\
\hline Some NY metro exposure & $1.998 \%$ & $0.390 \%$ \\
\hline No NY metro exposure & $-2.075 \%$ & $-3.366 \%$ \\
\hline t statistic & $2.647^{*}$ & $3.337^{*}$ \\
\hline $\mathrm{P}(\mathrm{T} \leq \mathrm{t})$ one-tail & 0.007 & 0.001 \\
\hline t critical one-tail & 1.708 & 1.708 \\
\hline $\mathrm{P}(\mathrm{T} \leq \mathrm{t})$ two-tail & 0.014 & 0.003 \\
\hline t critical two-tail & 2.060 & 2.060 \\
\hline \multicolumn{3}{|c|}{ Standard deviation of price change } \\
\hline Some NY metro exposure & $5.683 \%$ & $3.493 \%$ \\
\hline No NY metro exposure & $1.676 \%$ & $2.344 \%$ \\
\hline F statistic & 0.087 & 0.450 \\
\hline $\mathrm{P}(\mathrm{F} \leq \mathrm{f})$ one-tail & 0.000 & 0.081 \\
\hline F critical one-tail & 0.390 & 0.390 \\
\hline \multicolumn{3}{|c|}{ Panel B: NY REITs versus DJIA } \\
\hline & close-to-open & close-to-close \\
\hline \multicolumn{3}{|c|}{ Average price change } \\
\hline Some NY metro exposure & $1.998 \%$ & $0.390 \%$ \\
\hline DJIA & $-6.798 \%$ & $-8.119 \%$ \\
\hline t statistic & $4.095^{*}$ & $3.667^{*}$ \\
\hline $\mathrm{P}(\mathrm{T} \leq \mathrm{t})$ one-tail & 0.000 & 0.000 \\
\hline t critical one-tail & 1.684 & 1.684 \\
\hline $\mathrm{P}(\mathrm{T} \leq \mathrm{t})$ two-tail & 0.000 & 0.000 \\
\hline t critical two-tail & 2.021 & 2.021 \\
\hline \multicolumn{3}{|c|}{ Average standard deviation of price change } \\
\hline Some NY metro exposure & $5.683 \%$ & $3.493 \%$ \\
\hline DJIA & $6.505 \%$ & $7.682 \%$ \\
\hline F statistic & 0.763 & 0.207 \\
\hline $\mathrm{P}(\mathrm{F} \leq \mathrm{f})$ one-tail & 0.328 & 0.004 \\
\hline F critical one-tail & 0.388 & 0.388 \\
\hline
\end{tabular}




\section{Table 3. Cross-sectional REIT correlations}

This table reports cross-sectional correlations between observed price changes (from the close on Monday September 10, 2001 to the open of Monday September 17, 2001) for the REITs in our sample, their square footage in the New York metropolitan area (NY metro, including Northern NJ, Southern CT, Long Island, and Westchester, but excluding downtown Manhattan), their percentage square footage of office space in New York City (PctNYC, computed as the ratio between New York City office square feet and square feet of office space in the entire REIT portfolio), and their percentage square footage in the entire New York metropolitan area (PctNYMetro, computed as the ratio between New York metropolitan office square feet, excluding Manhattan, and square feet of office space in the entire REIT portfolio).

\begin{tabular}{r|cccc}
\hline \hline & Price change & NY metro & PctNYC & PctNYMetro \\
\cline { 2 - 6 } Price change & 1.000 & & & \\
NY metro & 0.827 & 1.000 & & \\
PctNYC & 0.603 & 0.644 & 1.000 & \\
PctNYMetro & 0.781 & 0.842 & 0.746 & 1.000 \\
\hline \hline
\end{tabular}




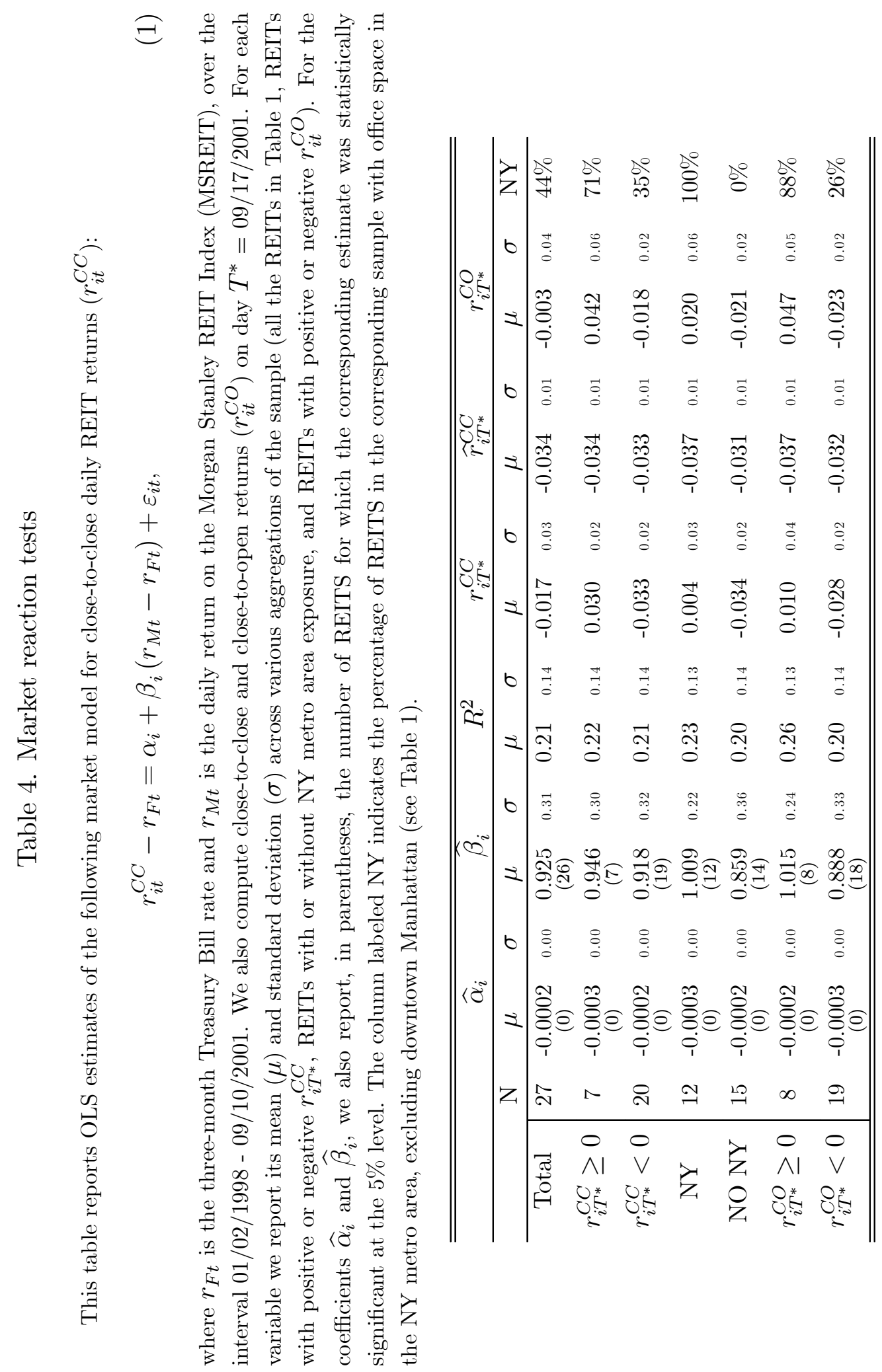

崩 
Table 5a. Real asset behavior: NAV, IRR, \& blend cap rates

This table reports estimates of excess quarterly REIT internal rates of return (or IRR $\left.\left(i r r_{i \tau}\right)\right)$ for 2001.Q4. Excess IRRs are computed in three steps. First, we estimate the following market model for the New York City IRR Index $\left(i r r_{N Y \tau}\right)$ :

$$
i r r_{\tau}^{N Y}-r_{F \tau}=\alpha+\beta\left(r_{U S \tau}-r_{F \tau}\right)+\eta_{\tau},
$$

where $r_{F \tau}$ is the three-month Treasury Bill rate and $r_{U S \tau}$ is the quarterly U.S. IRR Index from Korpacz Data (computed on unleveraged, all cash transactions). The model of Eq. (2) is estimated over 29 quarterly observations between 1994.Q2 and 2001.Q2. Second, the resulting coefficients' OLS estimates, $\widehat{\alpha}=0.0027$ (and a $t$-statistic of 2.27) and $\widehat{\beta}=0.8305$ (and a $t$-statistic of 11.66), with $R^{2}=83.43 \%$, are then used to measure the "normal" NY IRR $\widehat{i r r}_{\tau}^{N Y}$. Finally, excess IRR for each REIT when $\tau^{*}$ $=2001$. Q4 is computed as the difference between the percentage quarterly change in Net Asset Value (NAV) per share with respect to 2001.Q3, $i r r_{i \tau^{*}}$, and the corresponding benchmark $i r r_{i \tau^{*}}^{B}=\omega_{i} \widehat{i r r}_{\tau^{*}}^{N Y}+\left(1-\omega_{1}\right) r_{U S \tau^{*}}$, where $\omega_{i}$ is the percentage of the REIT $i$ 's office space in the NY metro area reported in Table 1. Each REIT's NAV is computed as the ratio between its TTMNOI and its blend cap rate. A REIT's TTMNOI is the difference between its Trailing Twelve Months Total Rental Revenue and the corresponding Property Operating Revenues. Individual blend cap rates are weighted averages of either actual (from NREI and ACLI) or expectational (from PWC) weighted cap rates for both New York and the U.S., with weights given by the REIT's exposure to the NY metro area (see Table 1 and Section 2). NEVs per share are computed to control for the possibility that the REITs added properties to their portfolios and financed the purchase with a secondary stock offering. For each excess IRR we report its mean $(\mu)$ and standard deviation $(\sigma)$ across various aggregations of the sample (all the REITs in Table 1, REITs with positive or negative $r_{i T^{*}}^{C C}$, REITs with or without NY metro area exposure, and REITs with positive or negative $r_{i T^{*}}^{C O}$, where $\left.T^{*}=09 / 17 / 2001\right)$. The column labeled NY indicates the percentage of REITs in the corresponding sample with office space in the NY metro area, excluding downtown Manhattan (see Table 1).

\begin{tabular}{|c|c|c|c|c|c|c|c|c|}
\hline & & \multicolumn{2}{|c|}{$i r r_{i \tau^{*}}^{N R E T}-i r r_{i \tau^{*}}^{B}$} & \multicolumn{2}{|c|}{$i r r_{i \tau^{*}}^{A C L I}-i r r_{i \tau^{*}}^{B}$} & \multicolumn{2}{|c|}{$i r r_{i \tau^{*}}^{P W C}-i r r_{i \tau}^{B}$} & \\
\hline & $\mathrm{N}$ & $\mu$ & $\sigma$ & $\mu$ & $\sigma$ & $\mu$ & $\sigma$ & NY \\
\hline Total & 27 & -0.048 & 0.09 & -0.013 & 0.09 & -0.034 & 0.09 & $44 \%$ \\
\hline$r_{i T^{*}}^{C C} \geq 0$ & 7 & -0.024 & 0.05 & 0.014 & 0.06 & -0.026 & 0.05 & $71 \%$ \\
\hline$r_{i T^{*}}^{C C}<0$ & 20 & -0.057 & 0.10 & -0.022 & 0.10 & -0.037 & 0.11 & $35 \%$ \\
\hline NY & 12 & -0.033 & 0.04 & 0.004 & 0.04 & -0.030 & 0.04 & $100 \%$ \\
\hline NO NY & 15 & -0.060 & 0.12 & -0.026 & 0.12 & -0.038 & 0.12 & $0 \%$ \\
\hline$r_{i T^{*}}^{C O} \geq 0$ & 8 & -0.029 & 0.04 & 0.009 & 0.05 & -0.036 & 0.03 & $88 \%$ \\
\hline$r_{i T^{*}}^{C O}<0$ & 19 & -0.056 & 0.11 & -0.022 & 0.10 & -0.034 & 0.11 & $26 \%$ \\
\hline
\end{tabular}


Table 5b. Real asset behavior: NAV, IRR, \& U.S. cap rates

This table reports estimates of excess quarterly REIT internal rates of return (or IRR $\left.\left(i r r_{i \tau}\right)\right)$ for 2001.Q4. Excess IRRs are computed in three steps. First, we estimate the following market model for the New York City IRR Index $\left(i r r_{N Y \tau}\right)$ :

$$
i r r_{\tau}^{N Y}-r_{F \tau}=\alpha+\beta\left(r_{U S \tau}-r_{F \tau}\right)+\eta_{\tau}
$$

where $r_{F t}$ is the three-month Treasury Bill rate and $r_{U S \tau}$ is the quarterly U.S. IRR Index from Korpacz Data (computed on unleveraged, all cash transactions). The model of Eq. (2) is estimated over 29 quarterly observations between 1994.Q2 and 2001.Q2. Second, the resulting coefficients' OLS estimates, $\widehat{\alpha}=0.0027$ (and a $t$-statistic of 2.27) and $\widehat{\beta}=0.8305$ (and a $t$-statistic of 11.66), with $R^{2}=83.43 \%$, are then used to measure the "normal" NY IRR $\widehat{\operatorname{irr}}_{\tau}^{N Y}$. Finally, excess IRR for each REIT when $\tau^{*}$ $=2001 . \mathrm{Q} 4$ is computed as the difference between the percentage quarterly change in Net Asset Value (NAV) per share with respect to 2001.Q3, $i r r_{i \tau^{*}}$, and the corresponding benchmark $i r r_{i \tau^{*}}^{B}=\omega_{i} \widehat{\operatorname{irr}}_{\tau^{*}}^{N Y}+\left(1-\omega_{1}\right) r_{U S \tau^{*}}$, where $\omega_{i}$ is the percentage of the REIT $i$ 's office space in the NY metro area reported in Table 1. Each REIT's NAV is computed as the ratio between its TTMNOI and the U.S. cap rate. A REIT's TTMNOI is the difference between its Trailing Twelve Months Total Rental Revenue and the corresponding Property Operating Revenues. Individual U.S. cap rates are either actual (from NREI and ACLI) or expectational (from PWC) cap rates for the U.S. (see Section 2). NEVs per share are computed to control for the possibility that the REITs added properties to their portfolios and financed the purchase with a secondary stock offering. For each excess IRR we report its mean $(\mu)$ and standard deviation $(\sigma)$ across various aggregations of the sample (all the REITs in Table 1, REITs with positive or negative $r_{i T^{*}}^{C C}$, REITs with or without NY metro area exposure, and REITs with positive or negative $r_{i t}^{C O}$, where $T^{*}=09 / 17 / 2001$ ). The column labeled NY indicates the percentage of REITs in the corresponding sample with office space in the NY metro area, excluding downtown Manhattan (see Table 1).

\begin{tabular}{|c|c|c|c|c|c|c|c|c|}
\hline & & \multicolumn{2}{|c|}{$\overline{i r r_{i \tau^{*}}^{N R E I}-i r r_{i \tau^{*}}^{B}}$} & \multicolumn{2}{|c|}{$\overline{i r r_{i \tau^{*}}^{A C L I}-i r r_{i \tau^{*}}^{B}}$} & \multicolumn{2}{|c|}{$\overline{i r r_{i \tau^{*}}^{P W C}-i r r_{i \tau^{*}}^{B}}$} & \\
\hline & $\mathrm{N}$ & $\mu$ & $\sigma$ & $\mu$ & $\sigma$ & $\mu$ & $\sigma$ & NY \\
\hline Total & 27 & -0.059 & 0.09 & -0.026 & 0.09 & -0.033 & 0.09 & $44 \%$ \\
\hline$r_{i T^{*}}^{C C} \geq 0$ & 7 & -0.049 & 0.05 & -0.016 & 0.05 & -0.023 & 0.05 & $71 \%$ \\
\hline$r_{i T^{*}}^{C C}<0$ & 20 & -0.063 & 0.11 & -0.029 & 0.11 & -0.037 & 0.11 & $35 \%$ \\
\hline NY & 12 & -0.054 & 0.04 & -0.020 & 0.04 & -0.028 & 0.04 & $100 \%$ \\
\hline NO NY & 15 & -0.064 & 0.12 & -0.030 & 0.12 & -0.038 & 0.12 & $0 \%$ \\
\hline$r_{i T^{*}}^{C O} \geq 0$ & 8 & -0.059 & 0.03 & -0.026 & 0.03 & -0.033 & 0.03 & $88 \%$ \\
\hline$r_{i T^{*}}^{C O}<0$ & 19 & -0.059 & 0.11 & -0.026 & 0.11 & -0.033 & 0.11 & $26 \%$ \\
\hline
\end{tabular}




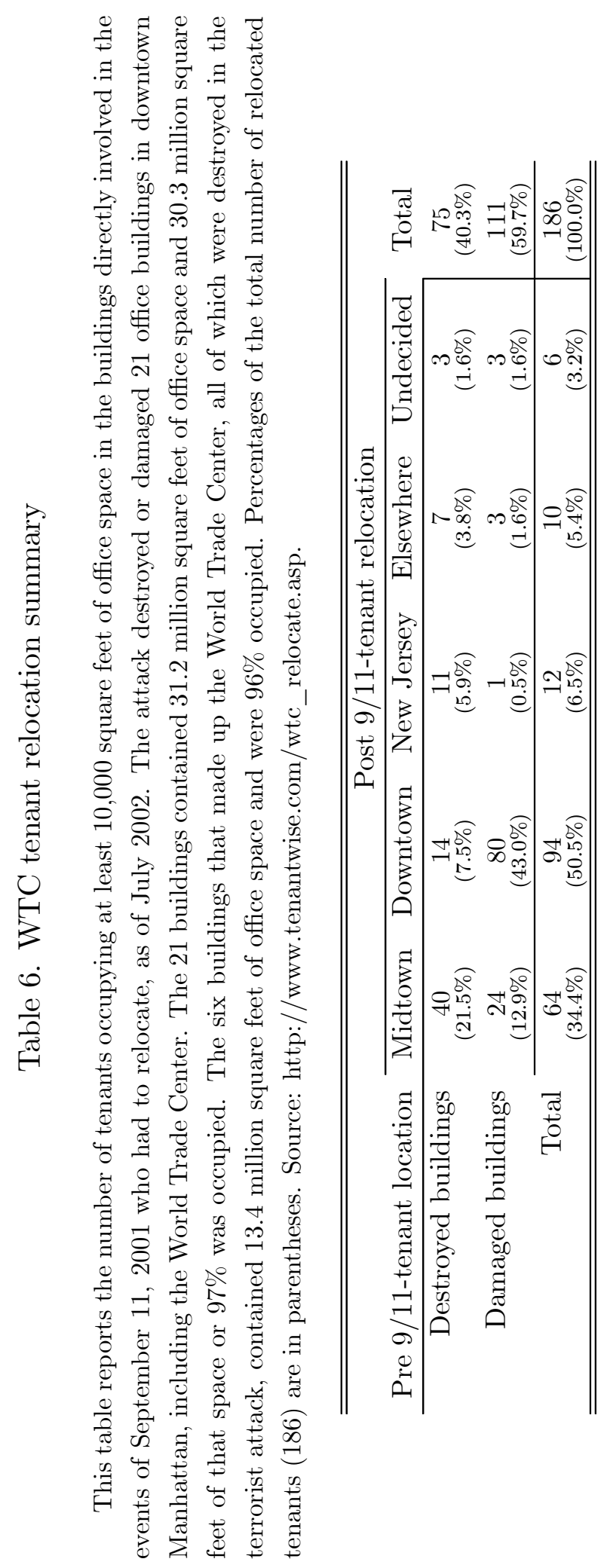

N 


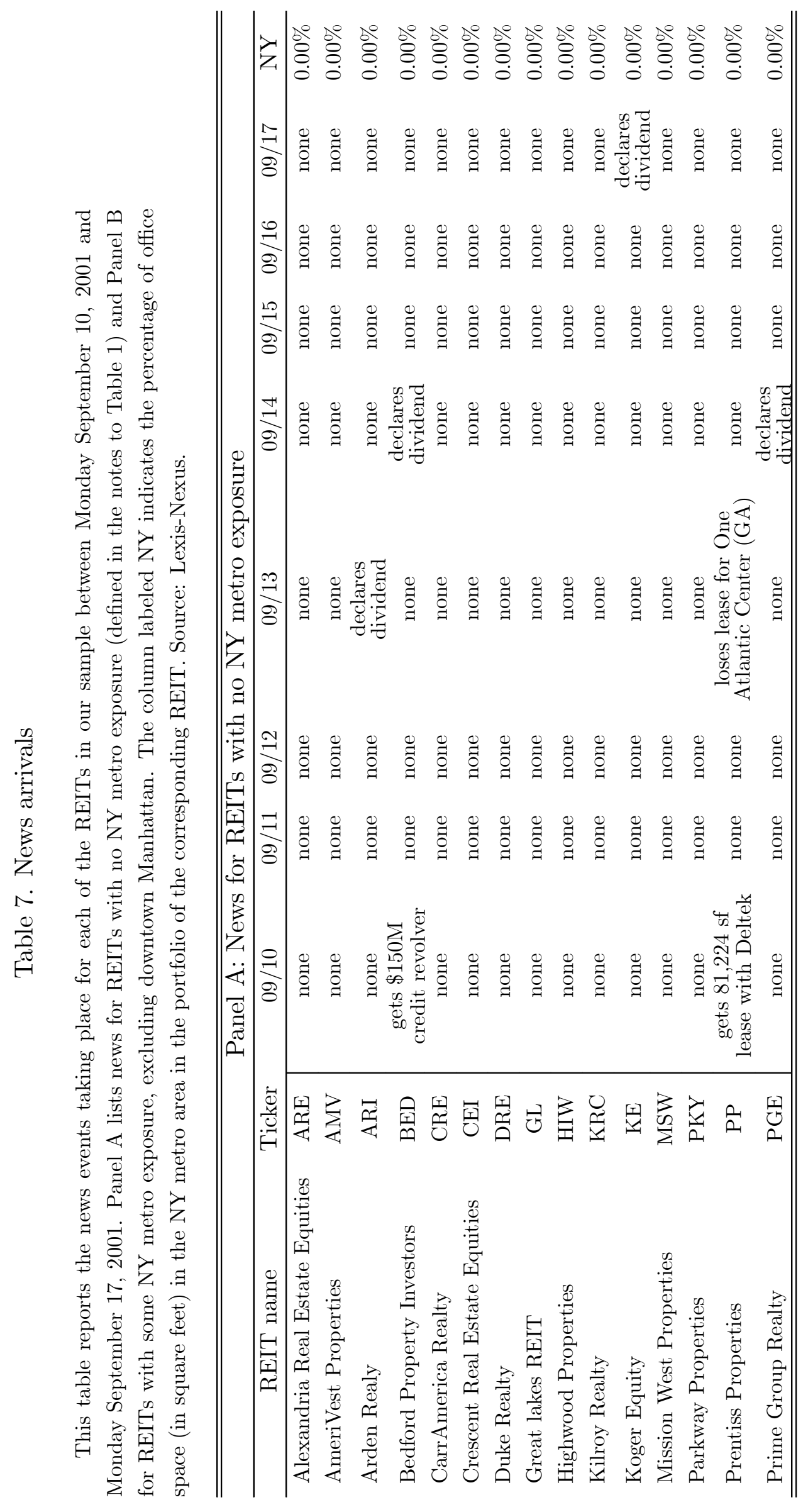




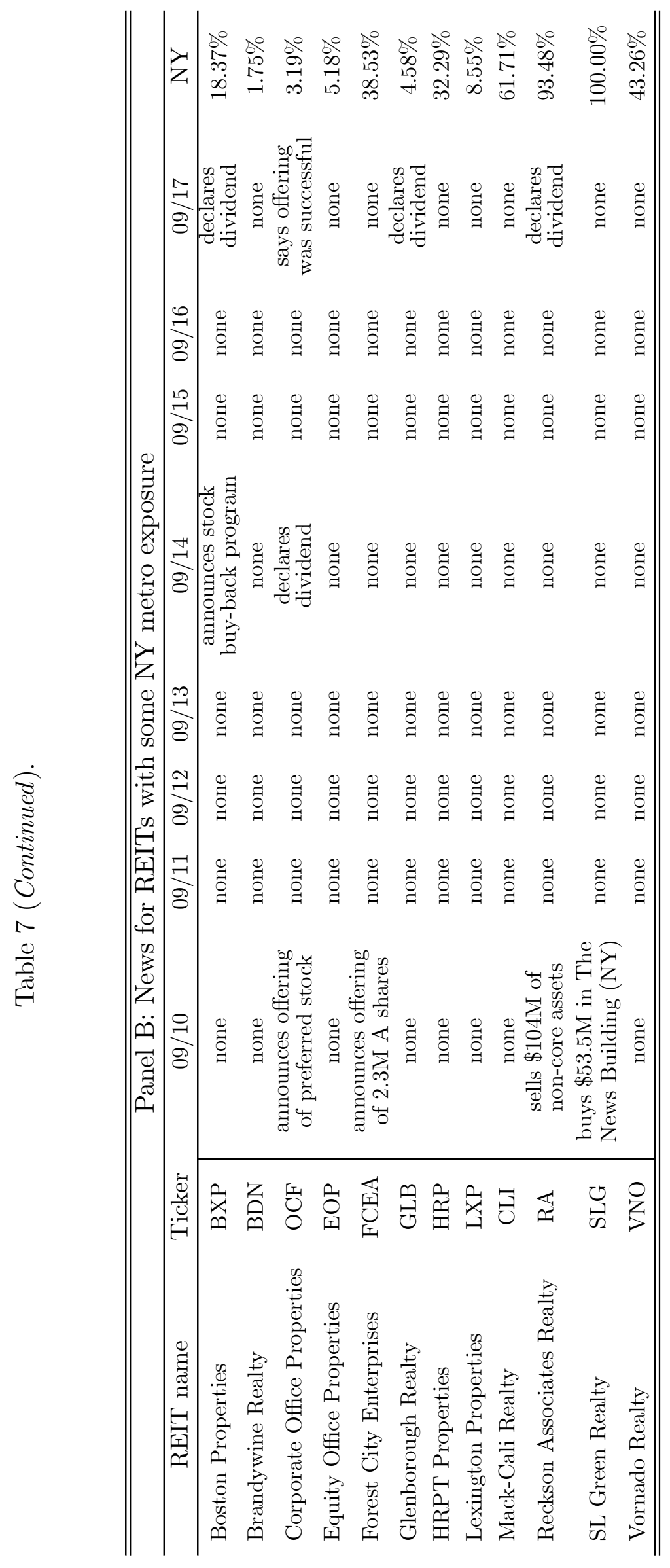


Table 9. Analysts' Recommendations for Mack-Cali (CLI)

This table displays various analysts' assessment of the impact of the WTC attacks on Mack-Cali (CLI) and their subsequent recommendations, from Investext. We collect analysts' reports issued immediately prior to the attack, issued 10 days subsequent to the attack (highlighted), and published one to three quarters after the event.

\begin{tabular}{|c|c|c|c|c|c|c|c|}
\hline \multicolumn{2}{|c|}{ REIT: Mack- Cali (CLI) } & \multirow[b]{2}{*}{ Recommendation } & \multirow[b]{2}{*}{$\begin{array}{c}\text { Change of } \\
\text { Target }\end{array}$} & \multirow[b]{2}{*}{$\begin{array}{l}\text { Price } \\
\text { Target }\end{array}$} & \multirow[b]{2}{*}{ EPS $01 E$} & \multirow[b]{2}{*}{ EPS O2E } & \multirow[b]{2}{*}{ EPS $03 E$} \\
\hline Date of Report & Analyst & & & & & & \\
\hline 16-Aug-01 & Morgan Stanley & Underperform & $\$ 26$ to NA & NA & 3.64 & 3.81 & -- \\
\hline 18-Sep-01 & Morgan Stanley & Outperform & NA to $\$ 32$ & 32 & 3.66 & 3.89 & .- \\
\hline 12-Now-01 & Morgan Stanley & Neutral & $\$ 32$ to $N A$ & NA & 3.66 & 3.74 & -- \\
\hline 22-Feb-02 & Morgan Stanley & Neutral & NA to $\$ 31.50$ & 31.50 & 3.66 & 3.74 & 3.97 \\
\hline 9-May-02 & Morgan Stanley & Equal Weight & $\$ 33$ to $\$ 33.50$ & 33.50 & -- & 3.73 & 3.97 \\
\hline 9-Aug-01 & Lehman Brothers & Market Perform & & 30 & 3.65 & 3.89 & -.- \\
\hline 2-0ct-01 & Lehman Brothers & Buy & & 34 & 3.67 & 3.96 & .- \\
\hline 9-Nor-01 & Lehman Brothers & Buy & & 34 & 3.64 & 3.81 & .- \\
\hline 10-Jan-02 & Lehman Brothers & Buy & & 33 & .- & 3.81 & 4.08 \\
\hline 21-Feb-02 & Lehman Brothers & Buy & & 33 & -- & 3.81 & 4.08 \\
\hline 8-May-02 & Lehman Brothers & Buy & & 34 & .- & 3.75 & 4.00 \\
\hline 10-Jun-02 & Lehman Brothers & Market Perform & & 34 & .- & 3.75 & 3.95 \\
\hline 10-Aug-01 & Banc of America & Underperform & & NA & 3.68 & 3.96 & -- \\
\hline 21-Sep-01 & Banc of America & Market Performer & NA to $\$ 32$ & 32 & 3.70 & 4.02 & \\
\hline 8-Now-01 & Banc of America & Market Performer & $\$ 32$ to NA & NA & 3.66 & 3.77 & -- \\
\hline 22-Feb-02 & Banc of America & Market Performer & & NA & -- & 3.74 & 4.05 \\
\hline 7-May-02 & Banc of America & Market Performer & & NA & -- & 3.72 & 3.99 \\
\hline 10-Aug-01 & Salomon Smith Barney & Neutral & & 30 & 3.67 & 3.90 & -.- \\
\hline 21-Sep-01 & Salomon Smith Barney & Outperform & & 33 & 3.67 & 4.10 & -- \\
\hline 8-Now-01 & Salomon Smith Barney & Outperform & & 33 & -- & 3.73 & 4.12 \\
\hline 25-Feb-02 & Salomon Smith Barney & Outperform & & 33 & .- & 3.72 & 4.00 \\
\hline 20-Mar-02 & Salomon Smith Barney & Outperform & & 34 & -- & 3.72 & 4.00 \\
\hline 7-May-02 & Salomon Smith Barney & Outperform & & 36 & -- & 3.72 & 4.00 \\
\hline 10-Aug-01 & Deutsche Banc & Market Perform & & 28 & 3.65 & 3.80 & -- \\
\hline 8-Now-01 & Deutsche Banc & Buy & & NA & 3.65 & 3.80 & -- \\
\hline 9-Nor-01 & Deutsche Banc & Market Perform & & NA & 3.65 & 3.70 & -- \\
\hline 25-Feb-02 & Deutsche Banc & Market Perform & & NA & -- & 3.70 & 3.95 \\
\hline 7-May-02 & Deutsche Banc & Market Perform & & NA & -- & 3.70 & 3.95 \\
\hline 30-Mar-01 & CS First Boston & Hold & & NA & NA & NA & -- \\
\hline 18-Sep-01 & CS First Boston & Strong Buy & & 34.50 & 3.65 & 3.85 & -- \\
\hline 8-May-02 & CS First Boston & Buy & & 38 & -- & 3.73 & 3.92 \\
\hline 24-Jun-02 & CS First Boston & Buy & & 38 & - & 3.73 & 3.92 \\
\hline
\end{tabular}




\section{Figure 1. Price changes for office REITs}

These figures plot the price change for each of the REITs in our sample, from the close on Monday September 10, 2001 to the open on Monday September 17, 2001, with respect to their corresponding amount of office space in the NY metro area (excluding downtown Manhattan), measured in square feet (000s, Figure 1a) and in percentage of total square footage (Figure 1b).

a) Square feet of office space

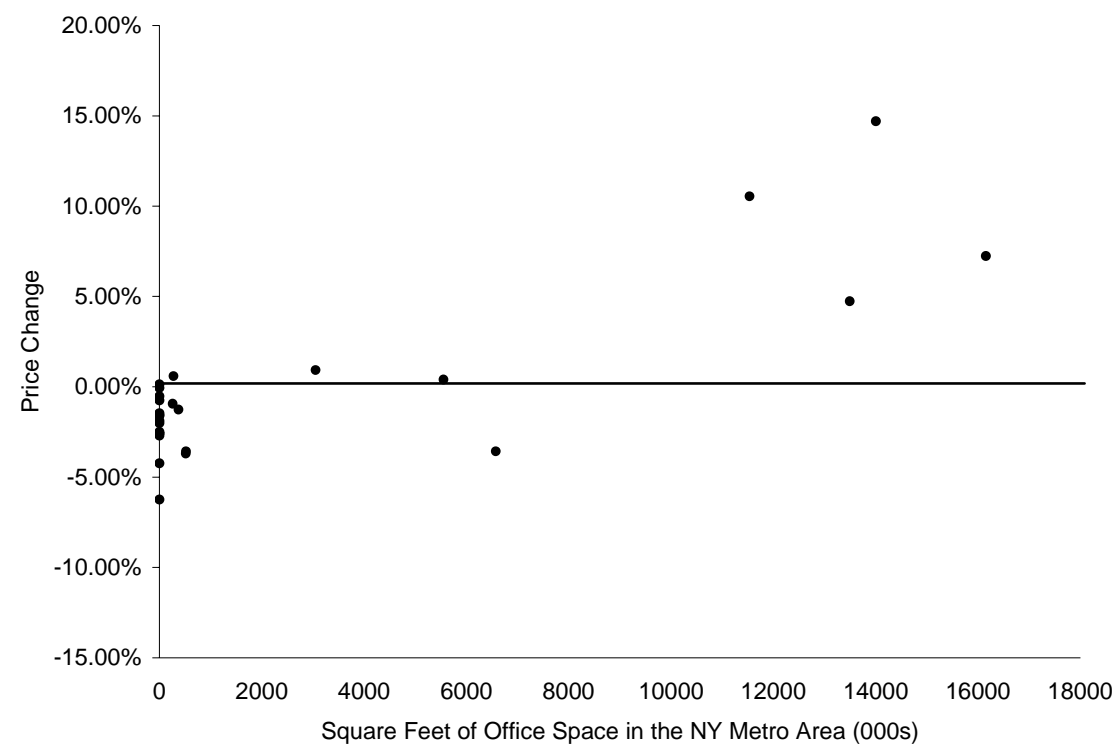

b) Percent of office space

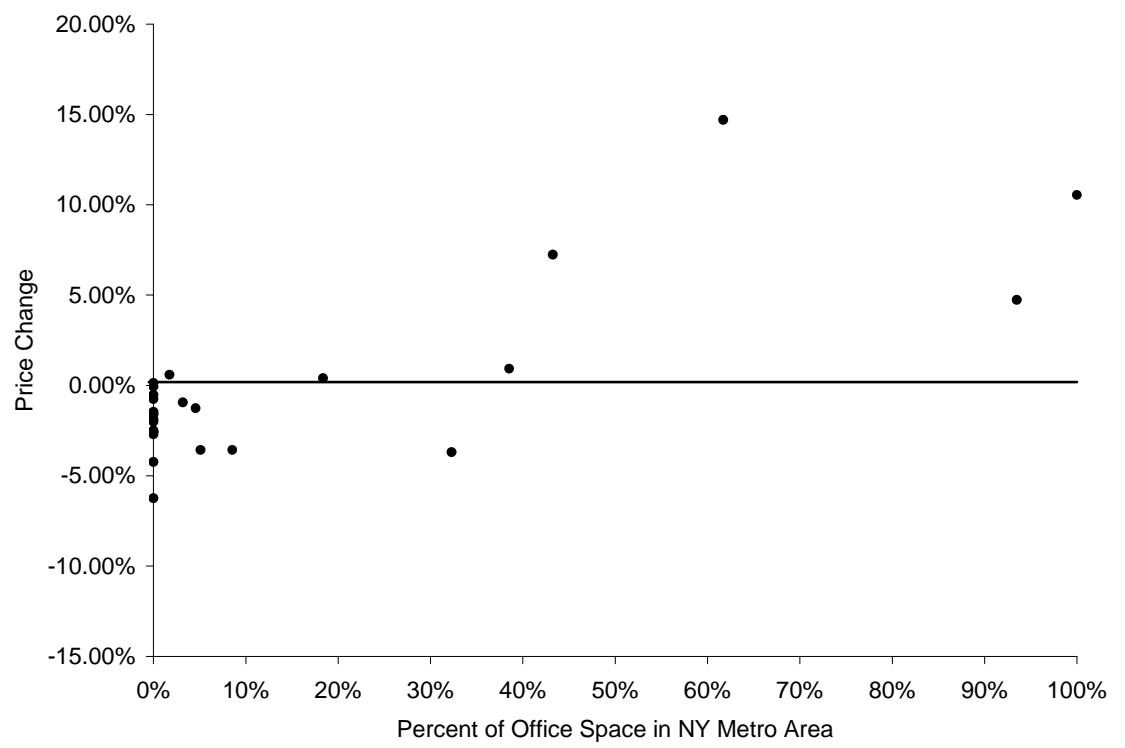




\section{Figure 2. Insider trading: NY REITs versus NO NY REITs}

This figure displays the cumulative sums of the ratios $\frac{B U Y_{t}-S E L L_{t}}{B U Y_{t}+S E L L_{t}}$, where $B U Y_{t}$ and $S E L L_{t}$ are the total number of shares bought and sold, respectively, by insiders in month $t$, between January 2001 and March 2002, for the REITs in our sample with some exposure to the NY metro area excluding downtown Manhattan (NY, solid line) and for the REITs with no such exposure (NO NY, dashed line), described in Table 1. The data are obtained from WRDS (Wharton Research Data Services ) TFN Insider Filing Data Files, which contain all insider activity as reported on SEC forms 3, 4, 5, and 144.

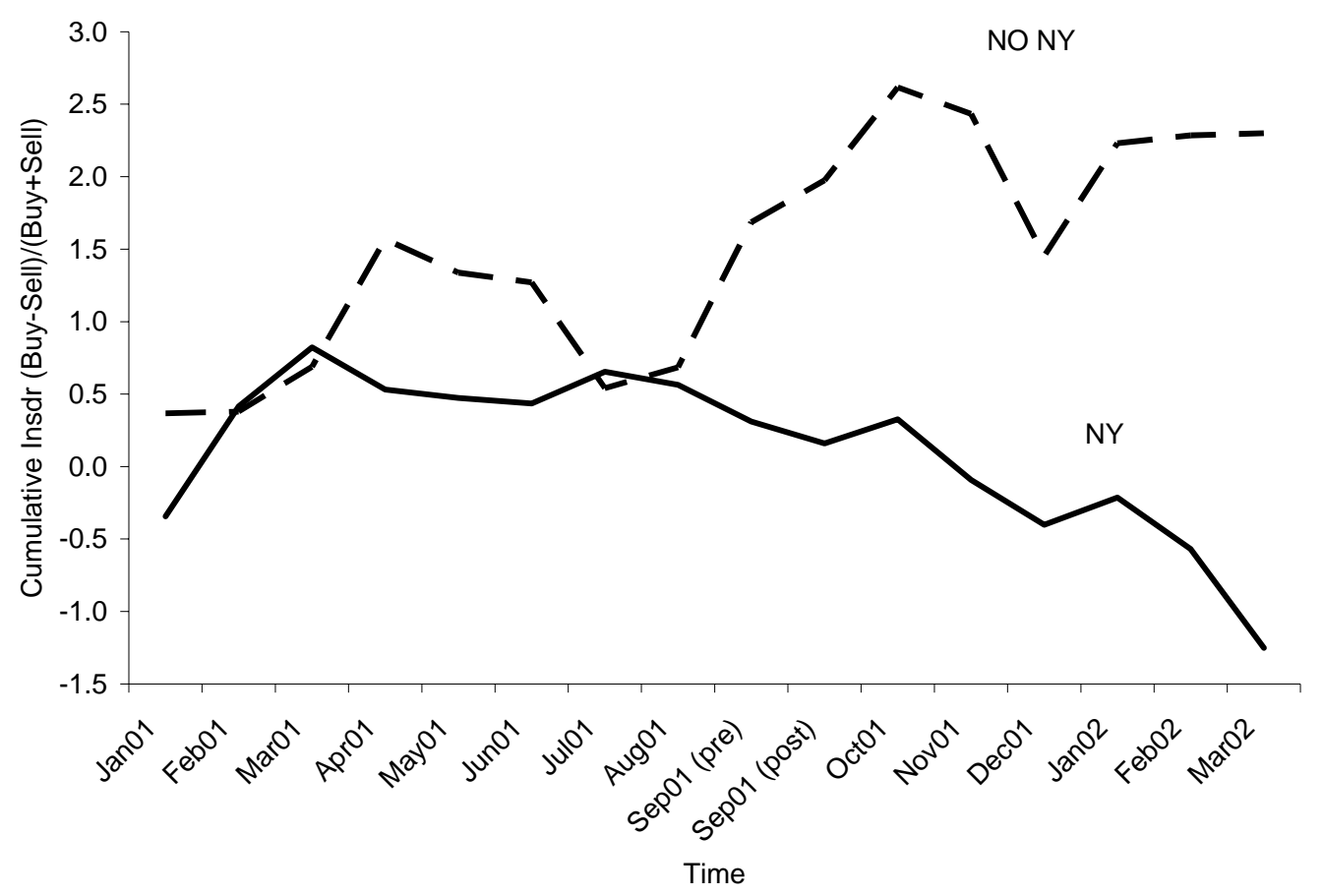


Figure 3. Cumulative abnormal returns for NY REITs

This figure plots cumulative abnormal returns (CARs, solid line) for the 12 REITs with some exposure to the NY metro office market excluding downtown Manhattan (NY) over the interval 09/17/2001 - 06/17/2002. The CAR series are generated by first estimating the following market model for close-to-close daily REIT returns $\left(r_{i t}^{C C}\right)$ :

$$
r_{i t}^{C C}-r_{F t}=\alpha_{i}+\beta_{i}\left(r_{M t}-r_{F t}\right)+\varepsilon_{i t}
$$

where $r_{F t}$ is the three-month Treasury Bill rate and $r_{M t}$ is the daily return on the Morgan Stanley REIT Index (MSREIT), over the interval 01/02/1998 - 09/10/2001 (as reported in Table 4), then computing abnormal returns (ARs) from Eq. (1) as the difference $r_{i t}^{C C}-\widehat{r}_{i t}^{C C}$ for each of the REITs in the two subsamples, and finally cumulating ARs over time and aggregating them across REITs. We also show $95 \%$ confidence intervals (dashed lines) under the null hypothesis of zero CARs.

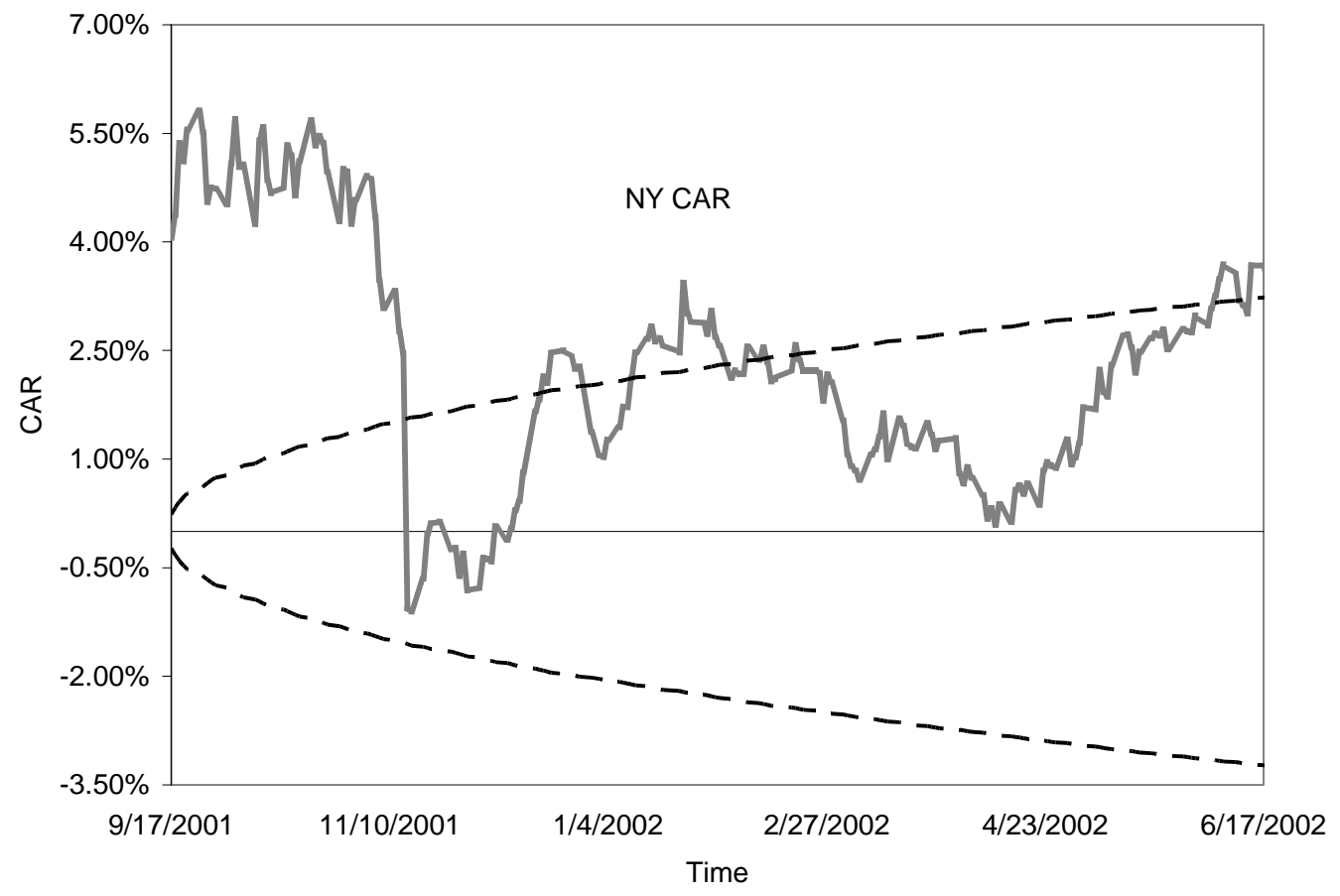

